Biological and Clinical Sciences Research Journal

ISSN: $2708-2261$

www.bcsrj.com

DOI: https://doi.org/10.54112/bcsrj.v2020i1.4

Biol. Clin. Sci. Res. J., Volume, 2020: 4

Original Research Article

\title{
ANTIFUNGAL AND ANTIBACTERIAL ACTIVITY OF ALOE VERA PLANT EXTRACT
}

\section{DANISH P, ALI Q, HAFEEZ MM, *MALIK A}

\author{
Institute of Molecular Biology and Biotechnology, The University of Lahore, Lahore, Pakistan \\ Corresponding author email: philemon.danish@gmail.com, arifuaf@yahoo.com
}

(Received $4^{\text {th }}$ January 2020; Accepted $24^{\text {th }}$ March 2020)

\begin{abstract}
Aloe vera is a well-known medicinal plant used in many therapeutic purposes. Naturally it is composed of many useful compounds that have ability to use for treatment of many diseases. The active compounds reported in this plant are saponins, sugar, enzymes, vitamins, aloesin, aloeemodin, aloin, acemannan aloemannan, aloeride, methylchromones, flavonoids, naftoquinones, sterols, minerals, anthraquinones, amino acids, lignin and salicylic acid and other different compounds including fat-soluble and water-soluble vitamins, enzymes, minerals, simple/complex sugars, organic acid and phenolic compounds. In this study aloe vera is used for antibacterial and antifulgal activity against different strains of bacteria and pathogenic fungal strains. Ethanol extract of Aloe vera leaves and roots is applied on these bacterial and fungal strains in different concentrations (15, 20, 25, 30 $\mu$ l). Bacillus cereus, Bacillus subtitis, Bacillus megaterium, Streptococcus pyogenes, Staphylococcus aureus, Escherichia coli, Pseudomonas aeruginosa, Acinetobacter baumannii, and some other bacterial strains are used for this study. Escherichia coli and Agrobacterium tumefacins shows zone of inhibition around $18 \mathrm{~mm}$ which consider as good result. Bacillus subtitis and Bacillus megaterium also shows good result around 16mm. Proteus mirabilis and Pseudomonas aeruginosa shows minimum zone of inhibition which is around $11 \mathrm{~mm}$. among all used fungal strains (fuserium oxysporum, Candida albicans, Aspergillus fumigatus, Aspergillus niger) fuserium oxysporum and Aspergillus niger shows excellent results around $19 \mathrm{~mm}$ both against root extract and leaves extract.
\end{abstract}

Keywords: Aloe vera, Bacterial strains, Fungal strains, Anti-bacterial, Anti-fungal

\section{Introduction}

In developing countries pathogenic microorganisms, fungus and bacterial strains are the main cause of life-threatening infections which leads to mortality and morbidity in immune-compromised patients (AlBari et al., 2006). Many antibiotics and antimicrobial agents are available in market which can kill these microbes or inhibit the growth of these microbes and involve in control of these pathogenic microorganisms. But the problem is that, these microbes are becoming more resistant day by day against these medicines even that many microbes are multidrug resistant. So treat of these disease causing and multidrug resistant microbes with several antibiotics influence an enormous threat on public health (Hajipour et al. 2012, Rojas et al. 2006). With the kill of pathogens, these medicines can also cause several side effects. So there is a need of natural, safer and cheaper source of antifungal and antibacterial agents. So for control of multidrug resistant microbes and safe use of medicines, people prefer to use of natural sources as medicines. Plants are the alternative source of antimicrobials that is safer, natural, cheaper and time tested source instead of other antibiotics (Van der et al.2001, Sharif et al. 2006, Dilhuydy et al. 2003). People know that many plants have a great medicinal ability, and for a long time ago people use plants throughout the globe for cure many infections. Since 2000BC plants are a great interest as phytomedicines both in Eastern and Western world. Every progressive civilization emphasizes the use of herbs. Ginseng is used by Chinese around 3000 years ago and to reduce the fever Americans use willow bark tea. As the use of herbal extracts is consider pure, simple and safe so the popularity of herbal products around the world may reflects the fact that many people do not believe in medical practices with allopathics (Sharif et al. 2006). The mostly used herbal compounds in dental field are ginseng, ginger, clove and garlic (Dilhuydy et al. 2003). Furthermore, in addition to the techniques used for processing and packaging, the strength, quality and purity of the drug is depend on the location, time and season of cultivation. According to WHO $80 \%$ people still use herbal

[Citation: Danish, P., Ali, Q., Haezz, M.M., Malik, A. (2020). Antifungal and antibacterial activity of Aloe vera plant extract. Biol. Clin. Sci. Res. J., 2020: 4. doi: https://doi.org/10.54112/bcsrj.v2020i1.4] 
medicines. Many plants are used for their medicinal ability worldwide. This study is focus on Aloe Vera plant. The word Aloe vera is derived from an Arabic word "Alloeh" means that "shining bitter substance" and the "Vera' is a Latin word means "true". Aloe vera is an herb that is used for over 2000 years, and has a great ability to use in phytotherapy or phytomedicines. It is cactus like plant that has around 360 species and grows in hot dry climate, and now a days it have high demand that's why it is cultivating in large scale (Newall et al. 1996). Egyptian scientist regarded Aloe vera "the plant of immortality" and around 2000 years ago Greeks called it as "universal panacea

It's an eminent medicinal plant belongs to a family liliaceae (Reynolds et al.1999, Kawai et al. 1993,). It's almost found throughout the globe but it grows best in hot tropical environments. It has high water contents which is ranges from $99.0-99.5 \%$. Because it has high capacity for holding of water so it is use for keep moisturize the skin. and any damaged on skin can be treated by its gel as its gel enhance the restoration of wound and stimulate the cell growth, Stomach ailments, constipation, thermal burn, sunburn, injuries caused by radiations, skin disease, inflammatory effect, diabetes, ulcer etc. can be treat by the use of Aloe vera gel (Foster et al 1999). Now a days many juice products of Aloe vera are available in market and it's consider that many gastrointestinal problems can be treated by A.vera juice, whenever mucus membrane of stomach got any damage or irritation, in many regions A.vera juice can be preferred to drink for the protection and healing of it (Eshun et al. 2004). Several researches also proposes that body's immune system can be stimulate by the gel of Aloe vera (Davis et al,. 1994) It's also used in many products such as pharmaceutics, cosmatics and in food industry etc. (Klein et al.1988). Rather than 99.0-99.5\% water the others $0.5-1.0 \%$ is testified to comprise over 200 active compounds and 75 nutrients. The active compounds reported in this plant are saponins, sugar, enzymes, vitamins, aloesin, aloeemodin, aloin, acemannan aloemannan, aloeride, methylchromones, flavonoids, naftoquinones, sterols, minerals, anthraquinones, amino acids, lignin and salicylic acid and other different compounds including fat-soluble and water-soluble vitamins, enzymes, minerals, simple/complex sugars, organic acid and phenolic compounds (Radha et al, 2014). A. vera gel have high moleculer weight compounds which demonste benificial effect. Lactine like proteins (Bajwa et al., 2007), polysacchrides (Subramanian et al., 2006) and postagladins (Guillette et al,. 1991), Manos-6phosphate shows a role in the healing of wound (Davis et al,. 1994), bradykinin-degrading glycoproteins may shows anti inflamatory effect (Yagi et al., 2002). For antiviral properties anthraquinones have been studied from various plants (Sydiskis et al., 1991).

The plant consists of two parts outer covering and a parenchyma aloe gel which is almost colorless and present inside the outer covering. Based on in vivo and in vitro study both these two parts shows medicinal properties. Total extract of the plant shows antibacterial, antifungal, anti-inflammatory and antiarthritic properties (Newall et al. 1996, Kumar et al. 2015). The Aloe vera extract have been developed, particularly sensitive to a variety of bacteria, Gramnegative pathogen, Gram-positive pathogens and some fungal pathogens. Inhibition Insulation compounds have clearly demonstrated their usefulness to various pathogenic microorganisms. It is elucidated that the application of plants in traditional medicine in the treatment of various diseases caused by these pathogenic strains. Plants used in conventional medicine, as well as plants used in the treatment of various diseases of these pathogenic strains. In addition, identification of these antimicrobial compounds enhances their growth by studying the structure/activity of new antimicrobia. In this present study we observed the antibacterial and antifungal activity of ethanol extract of root and leaf of Aloe vera.

\section{Material and methods Sample collection}

Aloe vera is a medicinal plant which have an ability to do activity against many microbes. It is stem less plant and ts height ranges from $60-100 \mathrm{~cm}$. It have green to grey-green colored thick and fleshy leaves. But some verities show white flacks on their stem. Polymannans, acetylated mannans, anthrones and anthraquinone C-glycosides etc are the phytochemicals found in Aloe vera. The anthraquinones, such as emodin and various lectins are also found in it. This study is done in The University of Lahore, Pakistan. For this study plant sample is collect from three different localities (canal, pound and growing fields) of local area of chak N0.377/E.B, Burewala, Pakistan. After collect the plant, its washed under tap water to remove any dust particles and other insect larvae. After washing thoroughly, we did weight of whole plant by the use of electronic weight balance in plant tissue culture lab in the University of Lahore. Than separate the roots and shoot and weight the shoot and roots separately. After complete the weighing we cut the plant leaves into small pieces with the help of sterilized knife and put these pieces into sterilized jars and filled these jars with $99.5 \%$ ethanol and kept it for three days and stirred occasionally as shown in fig.1. After that we strained the sample with help of 
sterilized strainer. Than we process the strained sample in Colum chromatography (use silica gel) in plant tissue culture lab. After the Colum chromatography we use rotary evaporator for extraction to making final ethanol extract of Aloe vera, shown in fig.2, in pharmacy lab in university of the Lahore. Extraction of plant roots were also done with the same method. Now it's ready for check its activity against any microbe.

\section{Preparation of the assay}

We used the Kirby-Bauer (disc diffusion) method with some modifications and used the crude ethanol extract. The plant is cut into pieces, make ethanol extract of plant. And then prepare this sample with different concentrations of ethanol extract which are $15,20,25$ and $30 \mu \mathrm{g}$ respectively and kept it for 3 days and stirred occasionally. Microbial growth was subjected to these samples for 24 hours. Also prepared root sample for assay. Prepare ethanol extract of roots and prepared this root sample with different concentrations of ethanol extract which are $15,20,25$ and $30 \mu \mathrm{g}$ respectively and kept it for 3 days and stirred occasionally. Microbial growth is checked on these samples for 24 hours

\section{Inoculum preparation}

Stock cultures of bacteria and as well as fungus were prepared in microbiology lab. Prepared stock culture of gram negative bacteria Escherichia coli, Acinetobacter baumannii, Pseudomonas aerugenosa, Salmonella typhii, Agrobacterium tumefacins, Proteus mirabilis, Proteus vulgaris and gram positive bacteria bacillus cereus, bacillus subtitis, bacillus megaterium, streptococcus pyogenes, staphylococcus aureus, enterococcus faecalis and for fungal activity, prepared culture of fuserium oxysporum, Candida albicans, Aspergillus fumigatus, and Aspergillus niger. These Microbial cultures were stored on nutrient agar media, and store it at $4^{\circ} \mathrm{C}$. For experiment active culture was prepared in nutrient broth by the transfer of loopfull cells of stock cultures into test tube. Same procedure is done for each sample of bacterial cultures, as well as for each fungal cultures. And kept in incubator at $37^{\circ} \mathrm{C}$ for 24 hours. Agar disc diffusion was performed for this assay.

\section{Method for Disc Diffusion}

Nutrient agar media was used for check the antibacterial activity of given samples. Prepare media with specific concentration $(13 \mathrm{~g} / \mathrm{L})$ in dist. Water. Sterilize the media and petriplates, pour the media into petriplate and wait till it solidify. After solidify the media use the sterilized cotton bud for swabbing the bacterial culture on solid plates. And discs of different concentrations $(15,20,25,30 \mu \mathrm{l})$ were placed on media by the use of sterilized forceps. Incubate the plates into incubator at $37^{\circ} \mathrm{C}$ for 24 hours than observe the zone of inhibition, measure the diameter which determines the growth of bacteria and activity of that specific concentration of plant extract on disc. For check the antifungal activity of given samples we used Muller-Hinton agar (MHA) medium. Sterilize the media and petriplates and pour the media into petriplate and wait till it solidify. When the media had been solidified we use the sterilized cotton bud for swabbing the fungus culture on solid plates. And discs of different concentrations $(15,20,25,30 \mu \mathrm{l})$ were placed on media by the use of sterilized forceps. Incubate the plates into incubator at $37^{\circ} \mathrm{C}$ for 3 days than observe the zone of inhibition, measure the diameter which determine the growth of fungus and activity of that specific concentration of plant extract on disc.

\section{Results}

Antibacterial and antifungal activity of ethanol extract of Aloe Vera is checked against various pathogens and results are given bellow.

Antibacterial activity of Leaf extract against gram positive bacterial

In Antibacterial activity of Leaf extract against gram positive Bacillus subtitis shows $15 \mathrm{~mm}$, Bacillus cereus 13mm, Bacillus megaterium $14.5 \mathrm{~mm}$, Streptococcus pyogenes 13 and Staphylococcus aureus $14 \mathrm{~mm}$ as shown in fig 1 . Zone of inhibition at low concentrations are also shown in fig 1 . And also shown in graph 1 height zone of inhibition is 15 for Bacillus subtitis and lowest zone of inhibition is 13 for Bacillus cereus and Streptococcus pyogenes at concentration of $30 \mu \mathrm{l}$.

Antibacterial activity of Leaf extract against gram negative bacterial

In Antibacterial activity of Leaf extract against gram negative bacterial strains, Aloe vera shows high antibacterial activity against Echerichia coli and Agrobacterium tumefacins which is noted that around $18 \mathrm{~mm}$ zone of inhibition and shows lowest zone of inhibition among all our used strains which is around $11.5 \mathrm{~mm}$ at concentration of $30 \mu \mathrm{l}$. zone of inhibition measured at concentration of 10, 2025 and $30 \mu 1$ are also shown in fig 2 Enterococcus faecalis, Bacillus subtitis and Bacillus megaterium shows good result, means that Aloe vera have good antibacterial activity against our used gram positive strains.

Antibacterial activity of Root extract against gram positive bacteria

Antibacterial activity of Root extract against gram positive bacteria Aloe Vera shows good antibacterial activity against Bacillus subtitis, Bacillus megaterium and Enterococcus faecalis which is noted around $16 \mathrm{~mm}$ and lowest zone of inhibition is 13.5 against Bacillus cereus at concentration of $30 \mu \mathrm{g}$ as shown in fig 3.

[Citation: Danish, P., Ali, Q., Haezz, M.M., Malik, A. (2020). Antifungal and antibacterial activity of Aloe vera plant extract. Biol. Clin. Sci. Res. J., 2020: 4. doi: https://doi.org/10.54112/bcsrj.v2020i1.4] 


\section{Antibacterial activity of Root extract against gram positive bacteria}

Aloe vera root extract also testified good results against gram negative bacteria. In this study Antibacterial activity of Root extract against gram negative bacteria Agrobacterium tumefacins noted zone of inhibition of around $17.5 \mathrm{~mm}$. Aloe vera root extraxt also shows good antibacterial activity against Escherichia coli, shows zone of inhibition is around $16 \mathrm{~mm}$. Zone of inhibition measured at concentration of $10,20,25$ and $30 \mu \mathrm{l}$ are also shown in table. Shown in fig 4.

Antifungal activity of Leaf extract against pathogenic fungal strains

Antifungal activity of A.vera is also observed against several pathogenic fungus at different concentrations. Both the ethanol extracts of leaf and roots are applied on culture of different fungus by disc diffusion

method. Leaf extract shows excellent results against fuserium oxysporum and Aspergillus niger $18.5 \mathrm{~mm}$ and $18 \mathrm{~mm}$ zone of inhibition respectively but the measure of zone of inhibition against other used fungus is also shows good results as given in fig 5 .

Antifungal activity of Root extract against pathogenic fungal strains

Antifungal activity of Root extract against pathogenic fungal strains also shows good results. Zone of inhibition is measured and at different concentrations. Zone of inhibition against fuserium oxysporum is measured around $19 \mathrm{~mm}$ which shows that ethanol extract of A.vera Roots have good antifungal activity. Aspergillus niger also shows good antifungal results zone of inhibition is measured around $18 \mathrm{~mm}$. other used fungus also shows good results as shown in fig 6.

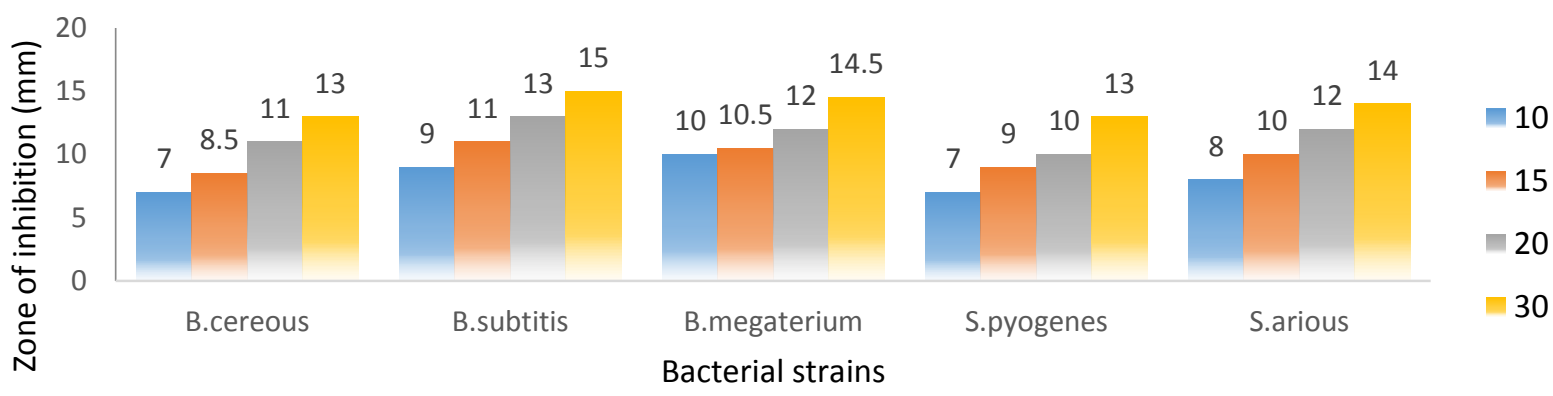

Fig 1. Anti-bacterial activity of leaf extract against gram+ve bacteria

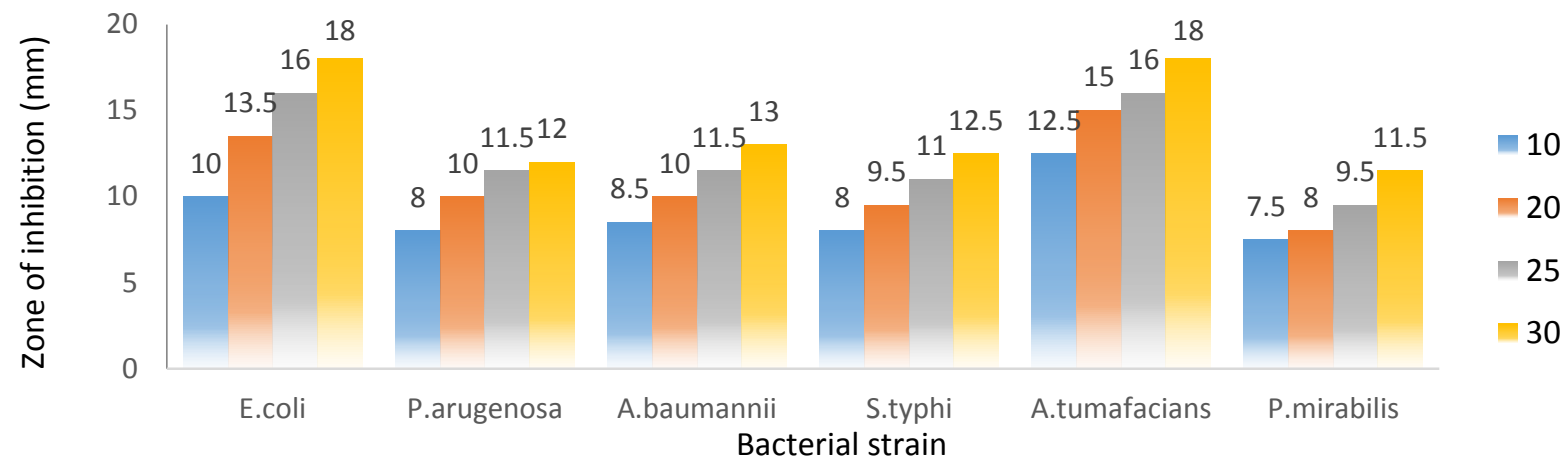

Fig 2. Anti-bacterial activity of leaf extract against gram-ve bacteria

[Citation: Danish, P., Ali, Q., Haezz, M.M., Malik, A. (2020). Antifungal and antibacterial activity of Aloe vera plant extract. Biol. Clin. Sci. Res. J., 2020: 4. doi: https://doi.org/10.54112/bcsrj.v2020i1.4] 


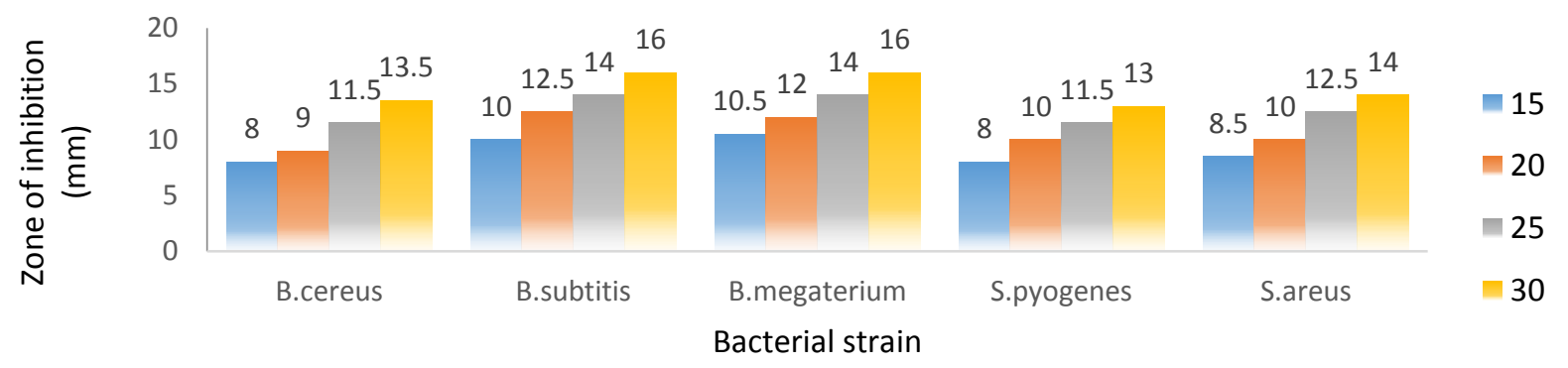

Fig 3. Anti-bacterial activity of root extract against gram+ve bacteria

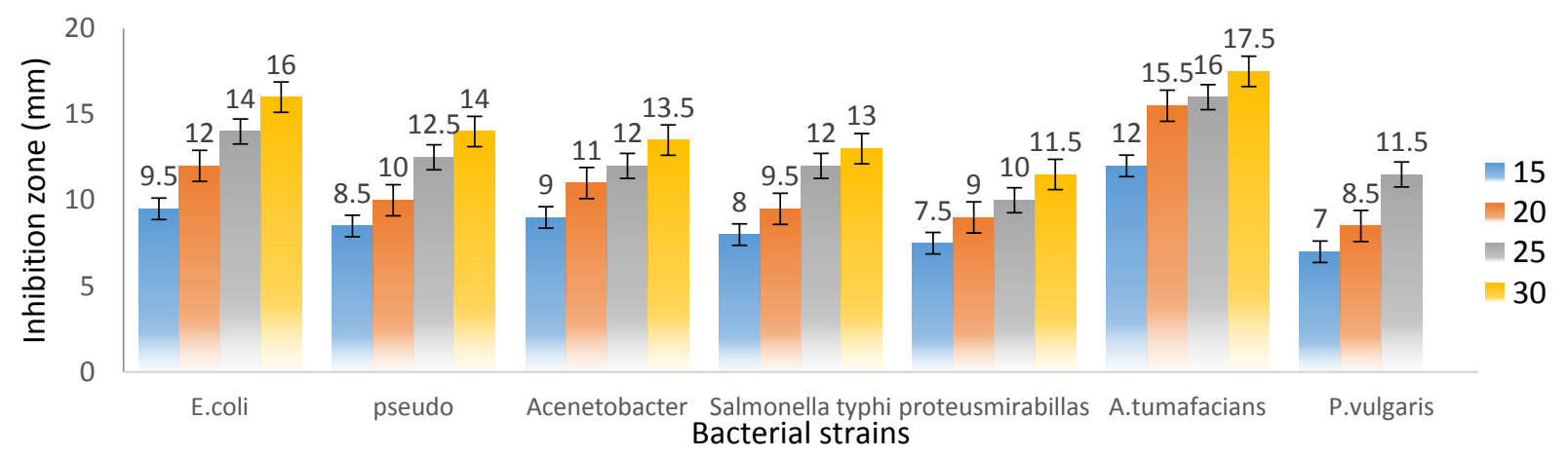

Fig 4. Antibacterial activity of Root extract against gram negative bacteria

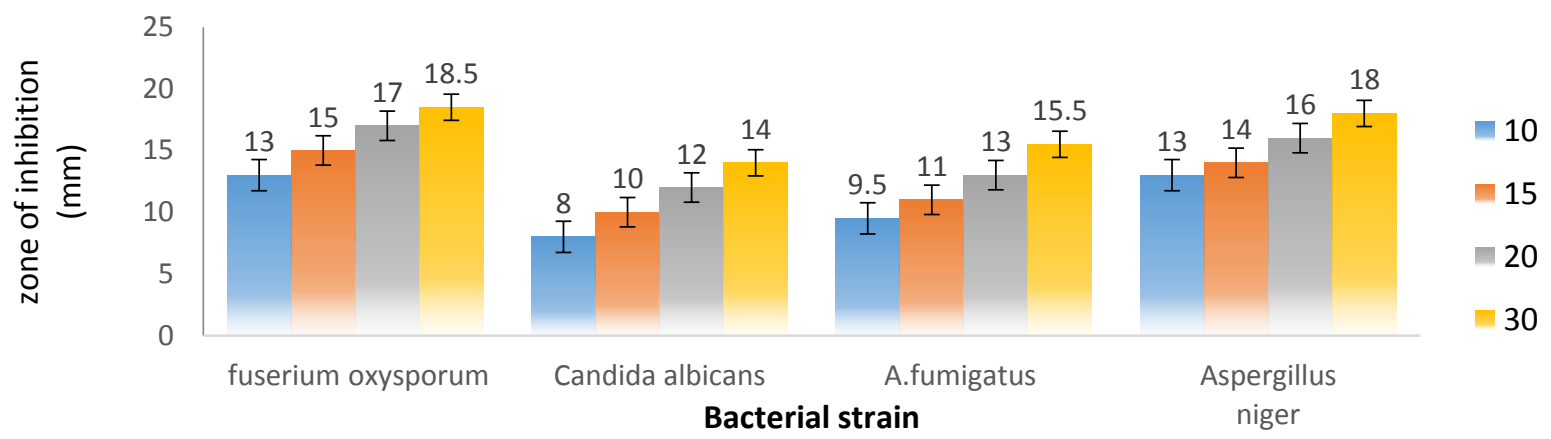

Fig 5. Antifungal activity of Leaf extract against pathogenic fungal strains

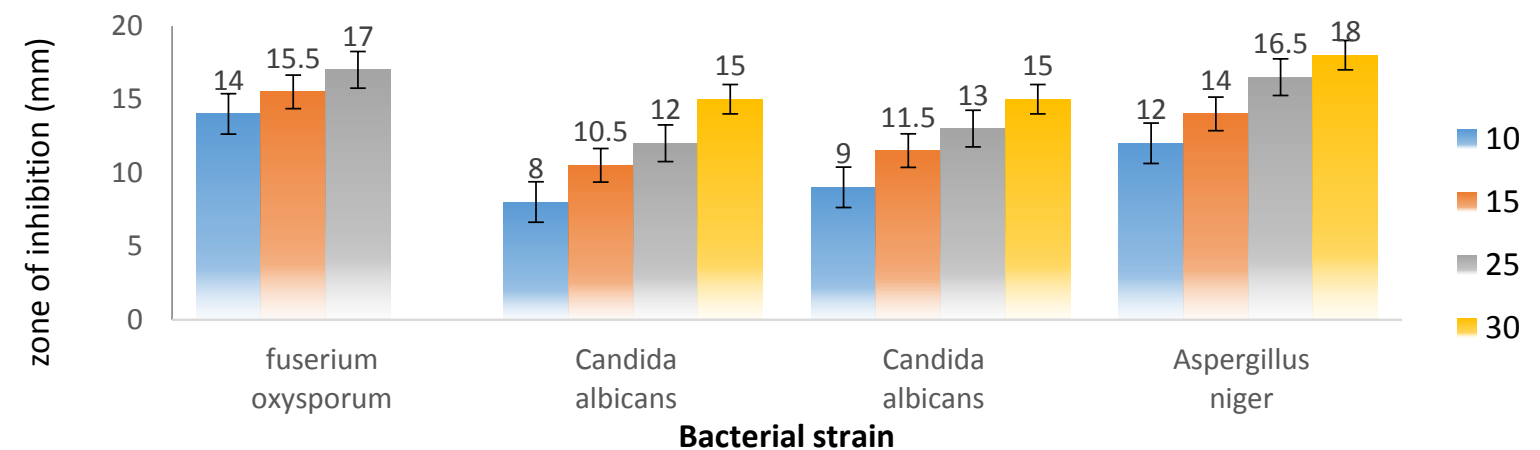

Fig 6. Antifungal activity of Root extract against pathogenic fungal strains

\section{Discussion}

[Citation: Danish, P., Ali, Q., Haezz, M.M., Malik, A. (2020). Antifungal and antibacterial activity of Aloe vera plant extract. Biol. Clin. Sci. Res. J., 2020: 4. doi: https://doi.org/10.54112/bcsrj.v2020i1.4] 
In our present study ethanol extract of Aloe vera was investigated for antibacterial and anti-fungal activity. Inhibitory effect of all the used concentrations of both the leaves extract and root extract shows varying degree of inhibition of growth of used bacterial and fungal pathogens as shown in above figures (1-6). Different concentrations of ethanol extract (15, 20, 25 and $30 \mu \mathrm{l}$ ) of leaves and root is applied of bacterial and fungal growth by the use of disc diffusion method. With the increase of concentration, zone of inhibition is also increased maximum zone of inhibition is examined on highest concentration. The ethanol gel extracts of $A$. vera root and leaves showed highest degree of activity around 19 and ranges from 11-19 at highest concentration against the selected pathogens. Aqueous, acetone and ethanol extracts of the $A$. vera gel is used against some human and plant pathogens is examined by disc diffusion method for check the antimicrobial activity and phytocostituents (Ibrahim et al., 2011). Among the three extracts used by Ibrahim et al, acetone and ethanol extracts noted significant antimicrobial activity against all used pathogens. As compared to ethanolic and aqueous, Acetone extract was found quite impressive in antibacterial and antifungal activity. A. barbadensis leaf gel components for antimicrobial activity are studied by Cock (2008). RP-HPLC was done for fractionate the Methanolic extracts of $A$. barbadensis inner leaf gel, and a panel of bacteria and fungi is used for test the inhibitory effect of resultant fractions (Cock 2008). Antimicrobial Activity of Aloe barbadensis Miller Leaf Gel Components 4:2). Antimicrobial activity of ethanolic extract of leaf and gel is compared against Trichophyton mentagraphytes, $P$. aeruginosa, $S$. aureus, T. schoeleinii, C. albicans and M. canis in this antimicrobial activity, it has been found that $S$. aureus is inhibited by both the leaf and gel extract. $T$. mentagrophytes isonly inhibited by gel, while $C$. albicans and $P$. aeruginosa both are inhibited by leaf extract (Agarry and Osho 2005). A study was also conducted by Thiruppathi et al in which he used $A$. vera juice with different solvents viz, ethyl acetate, petroleum ether, hexane and ethanol to determine the antimicrobial activity. Following Gram positive bacteria (S. aureus, B. subtilis) and gram negative bacteria ( $P$. aeruginosa, E. coli, K.pneumoniae) are used for test the antimicrobial activity. Ethyl acetate and ethanol extract shows more antimicrobial activity which is $(1-9 \mathrm{~mm})$ and $(7-12 \mathrm{~mm})$ respectively. But the petroleum ether extract shows least inhibitory effect around 2mm (Guillette et al., 1991). Manos-6phosphate shows a role in the healing of wound (Davis et al,. 1994), bradykinin-degrading glycoproteins may shows anti-inflammatory effect
(Yagi et al., 1987). For antiviral properties anthraquinones have been studied from various plants (Sydiskis et al., 1991). In this study The bacterial and fungal strains used for study antimicrobial activity are usually involve with the incidence of urogenital tract, tonsillitis, scarlet fever, rheumatic fever, gastrointestinal tract and wound infection. These potent herbal remedies play a big advancement in fungal infection therapies and for its safe use especially in immunocompromised patients. The present of sponin, tanins, alkaloids, laktine and anthroquinones in Aloe vera extract may be play an important role in antifungal activity, since the action of antibacterial and antifungal of these phytochemicals have been well documented (Deeni and Hussain , 1991; Shale et al 1999). Furthermore, due to confirmation of popular use, the testified result of this study shows that extract of this plant could represent a good, nontoxic, less expensive than allopathic drugs and new source of antibacterial and antifungal activity. To investigate and isolate these compounds and to study their principles and their mechanism of action further studies are still in progress.

\section{CONCLUSION}

Its hope that this research can lead to create some possible vehicles Used to develop new and more potent Natural antimicrobials. The research is Identification of biologically active compounds and evaluate the mechanism of action of $A$. vera gel extract is related to certain organisms with human diseases. The results of this present study shows the importance of Aloe Vera in control of microbial infection and also used of this plant in folk medicines for the treatment of various diseases. And pay attention on the importance of Aloe Vera and to select it in further research and discovery of new bioactive compounds. The result of this study shows the ethanol extract of Aloe Vera have good antimicrobial properties even that it shows MIC at very low used concentration. And this study shows that we can use Aloe Vera as antimicrobial agent in new drugs for treatment of infectious disease in human. The results of this research have been developed particularly sensitive to a variety of bacteria the Gram-negative pathogen, Gram-positive pathogens and some fungal pathogens. Inhibition Insulation compounds has clearly demonstrated their usefulness to various pathogenic microorganisms. It is elucidated that the application of plants in traditional medicine in the treatment of various diseases caused by these pathogenic strains. Plants used in conventional medicine, as well as plants used 
in the treatment of various diseases of these pathogenic strains. In addition, identification of these antimicrobial compounds enhances their growth by studying the structure/activity of new antimicrobial

\section{Conflict of Interest}

There is no conflict of interest between authors.

\section{References}

Afzal, M., Ali, M., Hassan, R. A. H., Sweedan, N., \& Dhami, M. S. I. (1991). Identification of some prostanoids in Aloe vera extracts. Planta medica, 57(01), 38-40.

Agarry, O. O., \& Osho, B. I. (2005). ln-vitro and lnvivo Inhibition oí Aspergillus fumiga tus by Pseudomonas fluorescens Used as a Microbial Antagonist. Pakistan Journal of Nutrition, 4(6), 371-375.

AL Bari, M. A. A., Sayeed, M. A., Rahman, M. S., \& Mossadik, M. A. (2006). Characterization and antimicrobial activities of a phenolic acid derivative produced by Streptomyces bangladeshiensis a novel specis collected in Bangladesh. Research Journal of Medicine and Medical Sciences, 1(2): 77-81.

Bajwa, R., Shafique, S., \& Shafique, S. (2007). Appraisal of antifungal activity of Aloe vera. Mycopath, 5(1), 5-9.

Cock, I. E. (2008). Antimicrobial activity of Aloe barbadensis Miller leaf gel components. The Internet Journal of Microbiology, 4(2), 17.

Davis, R. H., DiDonato, J. J., Johnson, R. W., \& Stewart, C. B. (1994). Aloe vera, hydrocortisone, and sterol influence on wound tensile strength and anti-inflammation. Journal of the American Podiatric Medical Association, 84(12), 614-621.

Deeni, Y. Y., \& Hussain, H. S. N. (1991). Screening for antimicrobial activity and for alkaloids of Nauclea latifolia. Journal of Ethnopharmacology, 35(1), 91-96.

Dilhuydy, J. M. (2003). Patients' propensity for complementary and alternative medicine (CAM): a reality which physicians can neither ignore nor deny. Bulletin du cancer, 90(7), 623-628.

El Astal, Z. Y., Ashour, A. E. R. A., \& Kerrit, A. A. M. (2005). Antimicrobial activity of some medicinal plant extracts in Palestine. Pak. J. Med. Sci, 21(2), 187-193.

Eshun, K., \& He, Q. (2004). Aloe vera: a valuable ingredient for the food, pharmaceutical and cosmetic industries-a review. Critical Reviews in Food Science and Nutrition, 44(2), 91-96.

Ferro, V. A., Bradbury, F., Cameron, P., Shakir, E., Rahman, S. R., \& Stimson, W. H. (2003). In vitro susceptibilities of Shigella flexneri and Streptococcus pyogenes to inner gel of Aloe barbadensis Miller. Antimicrobial agents and chemotherapy, 47(3), 1137-1139.

Foster, S., 1999. Aloe vera: The succulent with skin soothing cell protecting properties. Herbs for Health magazine, pp.23-30.

Guillette Jr, L. J., Dubois, D. H., \& Cree, A. (1991). Prostaglandins, oviducal function, and parturient behavior in nonmammalian vertebrates. American Journal of PhysiologyRegulatory, Integrative and Comparative Physiology, 260(5), R854-R861.

Hajipour, M.J., Fromm, K.M., Ashkarran, A.A., de Aberasturi, D.J., de Larramendi, I.R., Rojo, T., Serpooshan, V., Parak, W.J. and Mahmoudi, M., 2012. Antibacterial properties of nanoparticles. Trends in biotechnology, 30(10): 499-511.

Ibrahim, M., Srinivas, M., \& Narasu, M. L. (2011). Phytochemical analysis and antimicrobial evaluation of Aloe vera gel against some human and plant pathogens. Asian Journal of Current Chemistry, 1(1), 1-11.

Kahlon, J. B., Kemp, M. C., Yawei, N., Carpenter, R. H., Shannon, W. M., \& McAnalley, B. H. (1991). In vitro evaluation of the synergistic antiviral effects of acemannan in combination with azidothymidine and acyclovir. Molecular biotherapy, 3(4), 214-223.

Kawai, K., Beppu, H., Koike, T., Fujita, K., \& Marunouchi, T. (1993). Tissue culture of Aloe arborescens Miller var. natalensis Berger. Phytotherapy Research, 7(7), S5-S10.

Kawai, K., Beppu, H., Shimpo, K., Chihara, T., Yamamoto, N., Nagatsu, T., ... \& Yamada, Y. (1998). In vivo effects of Aloe arborescens Miller var. natalensis Berger (Kidachi aloe) on experimental tinea pedis in guinea-pig feet. Phytotherapy Research: An International Journal Devoted to Pharmacological and Toxicological Evaluation of Natural Product Derivatives, 12(3), 178-182.

Klein, A. D., \& Penneys, N. S. (1988). Aloe vera. Journal of the American Academy of Dermatology, 18(4), 714-720.

Kumar, S., Yadav, M., Yadav, A., \& Yadav, J. P. (2015). Comparative analysis of antimicrobial activity of methanolic extracts of Aloe vera and quantification of aloe-emodin collected from different climatic zones of India. Archives of Clinical Microbiology, 6(2).1-10. 
Kumar, V., Al-Abbasi, F. A., Verma, A., Mujeeb, M., $\&$ Anwar, F. (2015). Umbelliferone $\beta$-Dgalactopyranoside exerts an anti-inflammatory effect by attenuating COX-1 and COX-2. Toxicology Research, 4(4), 1072-1084.

Leung, M. Y. K., Liu, C., Zhu, L. F., Hui, Y. Z., Yu, B., \& Fung, K. P. (2004). Chemical and biological characterization of a polysaccharide biological response modifier from Aloe vera L. var. chinensis (Haw.) Berg. Glycobiology, 14(6), 501-510.

Newall, C. A., Anderson, L. A., \& Phillipson, J. D. (1996). Herbal medicines. A guide for healthcare professionals. The pharmaceutical press.

Olaleye, M. T., \& Bello-Michael, C. O. (2005). Comparative antimicrobial activities of Aloe vera gel and leaf. African journal of biotechnology, 4(12). 1413-1414.

Radha, M. H., \& Laxmipriya, N. P. (2015). Evaluation of biological properties and clinical effectiveness of Aloe vera: A systematic review. Journal of traditional and complementary medicine, 5(1), 21-26.

Ramamoorthy, L., \& Tizard, I. R. (1998). Induction of apoptosis in a macrophage cell line RAW 264.7 by acemannan, a $\beta$ - $(1,4)$-acetylated mannan. Molecular Pharmacology, 53(3), 415-421.

Reynolds, T., \& Dweck, A. C. (1999). Aloe vera leaf gel: a review update. Journal of ethnopharmacology, 68(1-3), 3-37.

Rodriguez-Bigas, M., Cruz, N. I., \& Suarez, A. (1988). Comparative evaluation of aloe vera in the management of burn wounds in guinea pigs. Plastic and reconstructive surgery, 81(3), 386-389.

Rojas, J. J., Ochoa, V. J., Ocampo, S. A., \& Muñoz, J. F. (2006). Screening for antimicrobial activity of ten medicinal plants used in Colombian folkloric medicine: A possible alternative in the treatment of non-nosocomial infections. BMC complementary and alternative medicine, $6(1), 2$.

Shale, T. L., Stirk, W. A., \& van Staden, J. (1999). Screening of medicinal plants used in Lesotho for anti-bacterial and anti-inflammatory activity. Journal of Ethnopharmacology, 67(3), 347-354.

Sharif, M. D. M., \& Banik, G. R. (2006). Status and utilization of medicinal plants in Rangamati of
Bangladesh. Res. J. Agric. Biol. Sci, 2(6), 268273.

Subramanian, S., Kumar, D. S., Arulselvan, P., \& Senthilkumar, G. P. (2006). In vitro antibacterial and antifungal activities of ethanolic extract of Aloe vera leaf gel. Journal of plant Sciences, 1(4), 348-355.

Sydiskis, R. J., Owen, D. G., Lohr, J. L., Rosler, K. H., \& Blomster, R. N. (1991). Inactivation of enveloped viruses by anthraquinones extracted from plants. Antimicrobial agents and chemotherapy, 35(12), 2463-2466.

Tizard, I., Busbee, D., Maxwell, B., \& Kemp, M. C. (1994). Effects of acemannan, a complex carbohydrate, on wound-healing in young and aged rats. Wounds-A Compendium of Clinical Research and Practice, 6(6), 201-209.

van der Watt, E., \& Pretorius, J. C. (2001). Purification and identification of active antibacterial components in Carpobrotus edulis L. Journal of Ethnopharmacology, 76(1), 8791.

Yagi, A., Kabash, A., Okamura, N., Haraguchi, H., Moustafa, S. M., \& Khalifa, T. I. (2002). Antioxidant, free radical scavenging and antiinflammatory effects of aloesin derivatives in Aloe vera. Planta medica, 68(11), 957-960.

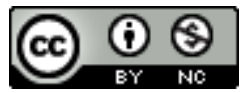

Open Access This article is licensed under a Creative Commons Attribution 4.0 International License, which permits use, sharing, adaptation, distribution and reproduction in any medium or format, as long as you give appropriate credit to the original author(s) and the source, provide a link to the Creative Commons licence, and indicate if changes were made. The images or other third party material in this article are included in the article's Creative Commons licence, unless indicated otherwise in a credit line to the material. If material is not included in the article's Creative Commons licence and your intended use is not permitted by statutory regulation or exceeds the permitted use, you will need to obtain permission directly from the copyright holder. To view a copy of this licence, visit http://creativecommons.org/licen ses/by/4.0/.

(C) The Author(s) 2021

[Citation: Danish, P., Ali, Q., Haezz, M.M., Malik, A. (2020). Antifungal and antibacterial activity of Aloe vera plant extract. Biol. Clin. Sci. Res. J., 2020: 4. doi: https://doi.org/10.54112/bcsrj.v2020i1.4] 